\title{
Marine tardigrade Halechiniscus jejuensis Chang et Rho, 2002 (Arthrotardigrada: Halechiniscidae) found in Vietnam
}

\author{
Alexei V. Tchesunov \\ Department of Invertebrate Zoology, Faculty of Biology, Moscow State University, Moscow, \\ 119991, Russia. \\ e-mail: AVTchesunov@yandex.ru
}

\begin{abstract}
Halechiniscus jejuensis Chang et Rho, 2002 is found and briefly described from a mangrove habitat in the Nha Trang area, Central Vietnam. The species was originally described at the southernmost point of the Korean Peninsula, hence the new find extends considerably the geographic distribution of the species southwards to the tropical zone. The Vietnamese specimens slightly differ from the Korean ones in shape and number of the lateral body expansions. A peculiar feature of the Vietnamese specimens is development of thread-like colonial prokaryotes on ventral surface of the head.
\end{abstract}

KEY WORDS: Halechiniscus jejuensis, marine tardigrades, mangroves, Vietnam.

\section{Морская тихоходка Halechiniscus jejuensis Chang et Rho, 2002 (Arthrotardigrada: Halechiniscidae) обнаружена во Вьетнаме}

\begin{abstract}
А.В. Чесунов
Кафедра зоологии беспозвоночных, Биологический факультет, Московский государственный университет им. М.В. Ломоносова, Москва, 119991, Россия.

e-mail: AVTchesunov@yandex.ru

PЕЗЮМЕ: Дано краткое описание тардиграды Halechiniscus jejuensis Chang et Rho 2002, обнаруженной в мангровом биотопе залива Нячанг, Центральный Вьетнам. Исходно вид описан из Корейского пролива (о. Чеджудо); настоящая находка расширяет географическое распространение вида далеко на юг, в тропическую зону. Вьетнамские особи немного отличаются от корейских числом и выраженностью латеральных выступов тела. Другой интересной особенностью вьетнамских H. jejuensis является развитие нитчатых колоний прокариотных организмов на вентральной стороне головы.
\end{abstract}

КЛЮЧЕВЫЕ СЛОВА: Halechiniscus jejuensis, Tardigrada, Вьетнам, мангровые сообщества, морские тардиграды. 


\section{Introduction}

The short communication belongs to a series of papers on meiofaunal diversity of mangrove habitats in the Nha Trang area, Khan Hoa Province, Central Vietnam. So far as I know, no marine tardigrade species were recorded along the Vietnam coast until recently (Guidetti, Bertolani, 2005; Degma, Guidetti, 2007). The marine tardigrades were found in sediment under young mangrove trees planted artificially in Dam Bay of the Tre Island. Besides Halechiniscus jejuensis two other tardigrade species of the genera Florarctus and Batillipes were collected; their descriptions will be published later. $H$. jejuensis was formerly known from only the type locality on the coast of Korean Peninsula (Chang, Rho, 2002).

\section{Material and methods}

The material is four specimens, two females and two individuals of unidentified sex. Samples of sediments were collected by a cylinder during the low tide and fixed with $4 \%$ paraformaldehyde solution on sea water in situ. The meiofauna stained by Bengal rosa was isolated by decantation and filtration through a sieve of $70 \mu \mathrm{m}$ mesh size. The tardigrades were extracted and put into watch glasses with alcoholglycerin-water mixture in proportion 29:1:70 and processed to glycerin by means of slow evaporation. Specimens were mounted into permanent glycerin slides with a paraffin ring, glass bead separators and glyceel seals. These slides were then studied with an Olympus BX51 light microscope equipped with Nomarski optics.

Abbreviations in text and figures: an - anus; $\mathrm{cA}$ - cirrus $\mathrm{A}$; $\mathrm{cE}$ - cirrus $\mathrm{E}$; ec - external (ventral) cirrus; go - gonopore; ic - internal (dorsal) cirrus; le — lateral body expansion; mc median cirrus; oc - ocellus; oo - ovum; p1p4 - sense organs of legs; pc - primary clava; sc - secondary clava; sr - seminal receptacle.

Аббревиатуры в тексте и на рисунках: an - анус; сA — циррус A; сE - циррус E; ес — внешний (вентральный) циррус; go гонопор; іс - внутренний (дорсальный) циррус; le — латеральный выступ тела; mc медианный циррус; ос — глазок; оо — яйцо; p1-p4 - сенсорные придатки на ногах I-IV; pc - первичная клава; sc — вторичная клава; $\mathrm{sr}$ - семенной рецептакул.

\section{Results}

Halechiniscus jejuensis Chang et Rho, 2002 Figs 1-3.

LOCALITY. Central Vietnam, Khan Hoa Province, Bay of Nha Trang, Tre Island, Dam Bay, sand sediment in the area of young mangrove trees Rhizophora stylosa. March-April 2006-2008.

REDESCRIPTION. Body short, cylindroids, 125-162 $\mu \mathrm{m}$ long and 45-75 $\mu \mathrm{m}$ wide. Dorsal cuticle very fine punctated in one specimen; dorsal punctuation in other three specimens obscure. The body cuticle dorsally and laterally covered with sticky foreign particles. In three specimens, three pairs of lateral body expansions clearly visible: first pair between I and II, second pair between II and III, third between III and IV leg pairs. In one specimen, five pairs of lateral body expansions observed: first expansions on I leg bases, second expansions between I and II legs, third expansions between II and III legs, fourth small expansions and fifth bigger expansions between III and IV legs. No other differences found in specimens having three and four pairs of expansions. The expansions not very prominent $(2-4 \mu \mathrm{m})$, rounded triangular, slightly slanting posteriorly; the third expansions the smallest if present. Legs stumpshaped but two-jointed, telescopic protrusible.

Cephalic region not divided into lobes of dorsal portion and ventral portion. Median cirrus up to $30 \mu \mathrm{m}$ long, staged, consists of three joints, directed antero-dorsally upwards and hence barely measurable if viewing the specimen dorsally or ventrally.

Internal (dorsal) cirrus up to $19 \mu \mathrm{m}$ long, consists of basal truncate conical cirrophore, scapus and flagellum; the latter also two-jointed; diameter gradually decreases from the base to the distal joint. 


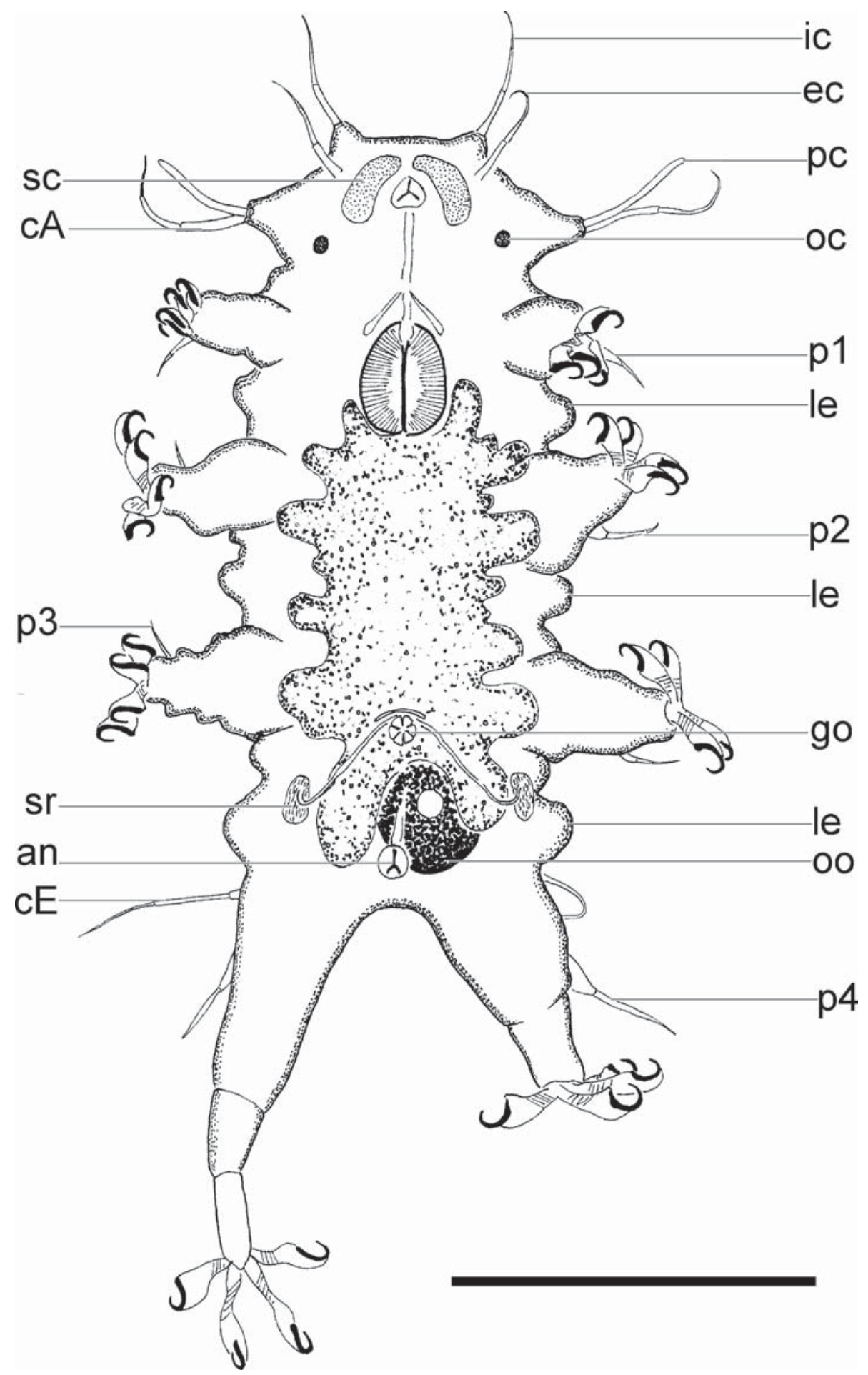

Fig. 1. Female Halechiniscus jejuensis, entire, ventral view. Scale bar $50 \mu \mathrm{m}$.

Рис. 1. Общий вид самки Halechiniscus jejuensis, вид с брюшной стороны. Масштаб 50 мкм. 

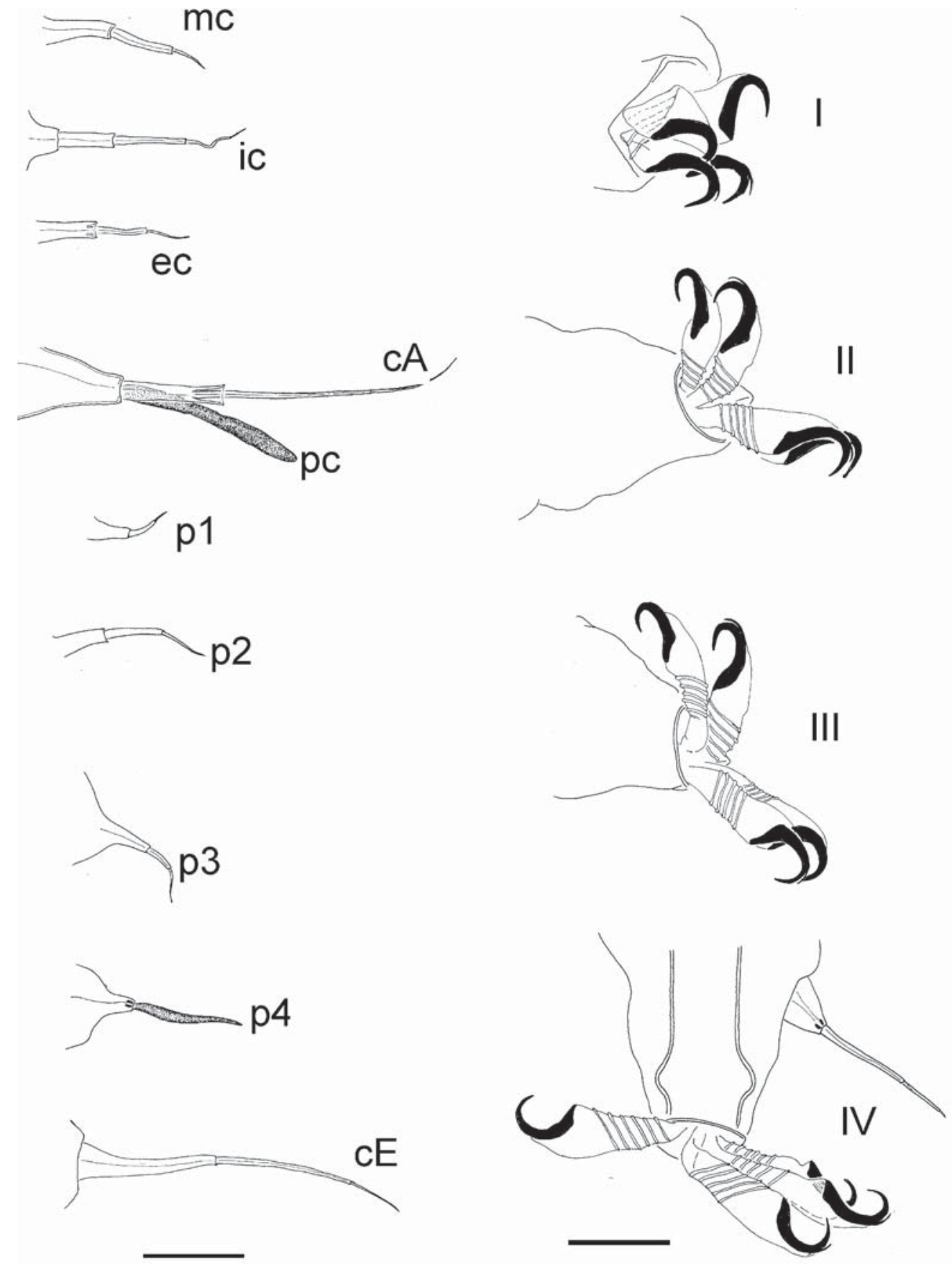

Fig. 2. Halechiniscus jejuensis, left-sided appendages. Left columns: sensory cirri. Right column: toes of IIV legs. Scale bars $10 \mu \mathrm{m}$.

Рис. 2. Halechiniscus jejuensis, придатки с левой стороны тела. В левой колонке сенсорные цирры, в правой колонке пальцы I-IV конечностей. Масштаб 10 мкм. 

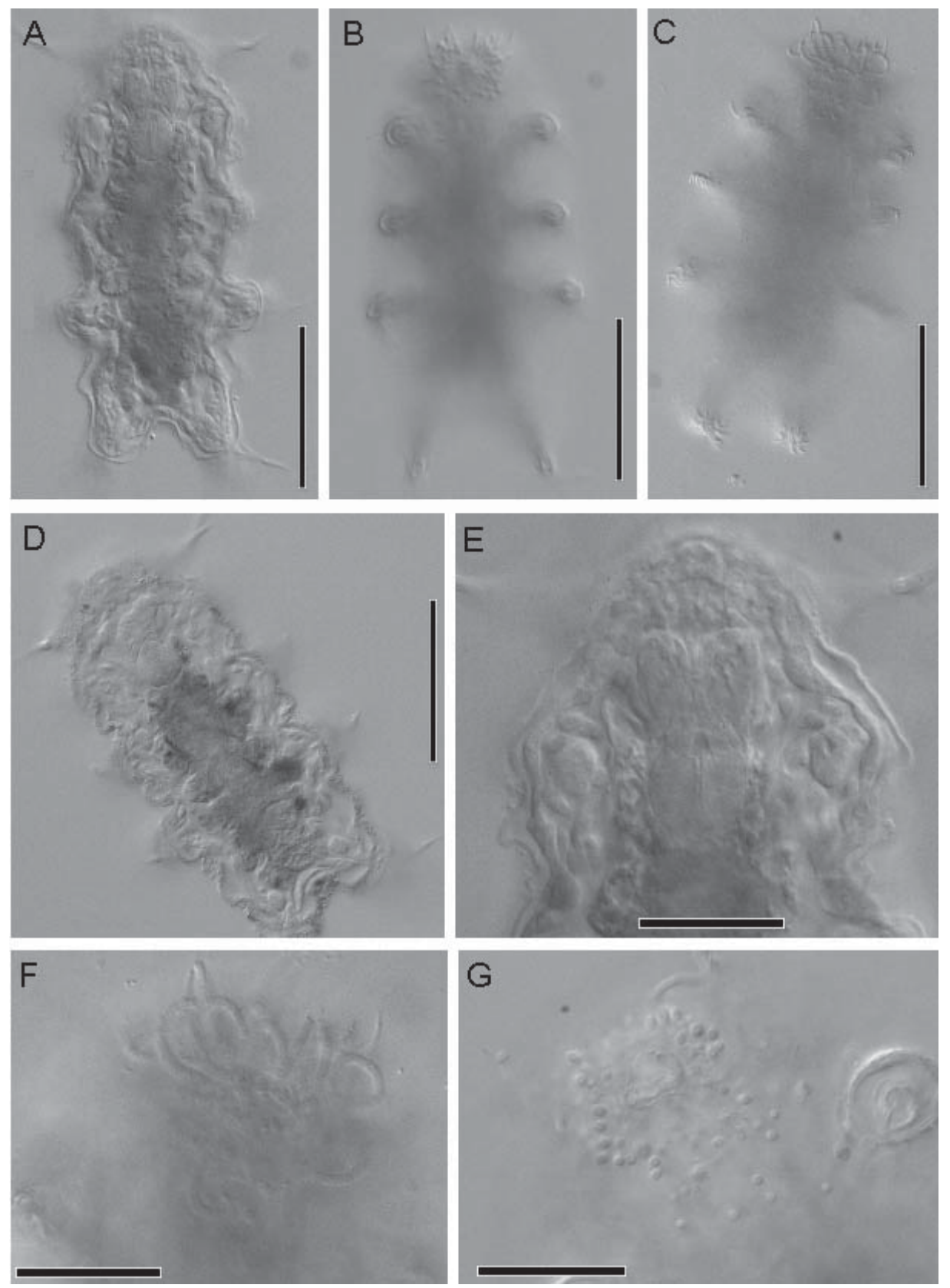

Fig. 3. Halechiniscus jejuensis, details.

A, D - entire, dorsal view (lateral expansions, coating of foreign particles sticked); B, C - entire, ventral view (ticket of colonial prokaryotes on ventral side of the head); E - anterior body dorsally, anterior lateral body expansions; F, $\mathrm{G}-$ head ventrally, filaments of colonial prokaryotes around the mouth. Scale bars: A-D $-50 \mu \mathrm{m} ; \mathrm{E}-\mathrm{G}-20 \mu \mathrm{m}$. Рис. 3. Детали строения Halechiniscus jejuensis.

$\mathrm{A}, \mathrm{D}$ - общий вид со спинной стороны (латеральные выступы тела, покров из посторонних частиц); В, Cобщий вид с брюшной стороны (нитчатые колонии прокариот на вентральной стороне головы); Е — передняя часть тела со спинной стороны, передняя пара латеральных выступов тела; F, G - голова с брюшной стороны, нити колониальных прокариот вокруг ротового отверстия. Масштаб: A-D - 50 мкм; E-G - 20 мкм. 
External (ventral) cirrus up to $16 \mu \mathrm{m}$ long, directed antero-ventrally downwards and hence barely measurable if viewing the specimen dorsally or ventrally.

Primary clavus up to $26 \mu \mathrm{m}$ long, cylindrical, sausage-shaped, attached to the top of the lateral conical projection, ventrally of the lateral cirrus; there are some light vesicles visible inside clavae in some specimens.

Lateral cirrus (cirrus A) up to $30 \mu \mathrm{m}$ long, attached to the top of the lateral conical projection, dorsally of the primary clavus, three-jointed (scapus + pr. flagellum + di. flagellum), longer than clava.

Secondary clava discernible not very clear because of the growth of prokaryotic epibionts. These are as two lateral bean-shaped spots 15 $\mu \mathrm{m}$ long and $9 \mu \mathrm{m}$ wide situated ventrally around the mouth opening. Their anterior narrowed ends converge close just anterior to the mouth while posterior broadened ends separated widely posterior to the mouth.

Ocelli are two lateral pigment globules 3$3.5 \mu \mathrm{m}$ in diameter situated internally at the base of the head lateral projections. The ocelli are doubled in one specimen and not visible in another one.

First leg cirrus short $(9 \mu \mathrm{m})$, looks twojointed. Second leg cirrus $16 \mu \mathrm{m}$ long, distinctly three-jointed. Third leg cirrus $15 \mu \mathrm{m}$ long, threejointed. Fourth leg cirrus $17 \mu \mathrm{m}$ long, looks twojointed: basal joint or maybe basal socle conical, distal joint short spindle-shaped. Cirrus E long $(40 \mu \mathrm{m})$, three-jointed.

Toes. Each leg terminates in four toes of equal length. The toes flat and thin, transparent, widened terminally and striated with five to six fine slanting ridges in the middle part. Each toe ends in a sickleshaped flat sclerotized claw. All the claws are equal in shape and size but two inner claws provided with an additional fine dorsal spur.

Mouth ventral, as a triradial slit (anterior and two lateroposterior radii) on a distinct smooth triangular area. Buccal tube straight, indistinct. Stilets short, situated just anterior to the bulb, poorly discernible, perhaps because of the initial paraformaldehyde fixation. Bulb slightly longitudinally oval, with distinct internal cuticular lumen and fine but clear radial muscular striation. Midgut with about six to nine pairs of indefinite lateral projections, greenish; no evident content inside. Anal opening ventral, situated between bases of the IV legs, as a longitudinal slit bifurcated posteriorly on a distinct smooth area.

Female gonopore situated midventrally just posterior to the bases of IV legs, as a six-lobed rosette $7-8 \mu \mathrm{m}$ in diameter. There is a transversal cuticular bar just anterior to the rosette. Paired lateral ducts directed latero-posteriad and terminated with ovoid seminal receptacles.

\section{Discussion}

Halechiniscus jejuensis has been initially found in shallow sublittoral zone of Jeju Island situated off the south corner of the Korean Peninsula (Chang, Rho, 2002). The new finding expands geographic and topic range of Halechiniscus jejuensis.

The specimens from Vietnam fit well to the original diagnosis both in structural features and measurements. However, Chang \& Rho indicated six pairs of lateral body expansions as one of the diagnostic characters of the new species while I can discern only three or five expansions. Another difference is a pair of eye spots clearly visible at the base of head lateral projections. I believe, these distinctions are not essential to doubt the species identification but expand the conception of variability.

A remarkable feature of our specimens is development of filiform colonial prokaryotes forming lush thicket around the mouth in all studied specimens Halechiniscus jejuensis. Of two other tardigrade species occurring together with $H$. jejuensis, the seemingly same prokaryotes dwell on specimens of Florarctus sp. also on the perioral area but not on specimens of Batillipes sp.

\section{Acknowledgements}

The project has been performed in and financed by Russian - Vietnamese Tropical Center for Science and Technology and partly by a grant of Leading Scientific School NSH- 
186.2008.4. The author thanks an anonymous reviewer for improvement of the manuscript.

\section{References}

Chang C.Y., Rho H.S. 2002. Taxonomic study of marine tardigrades from Korea II. Genus Halechi- niscus (Heterotardigrada, Arthrotardigrada, Halechiniscidae) // Korean J. Syst. Zool. Vol.18. No.1. P.91-98.

Degma P., Guidetti R. 2007. Notes to the current checklist of Tardigrada // Zootaxa. Vol.1579. P.41-53.

Guidetti R., Bertolani R. 2005. Tardigrade taxonomy: an updated checklist of the taxa and a list of characters for their identification // Zootaxa. Vol.845. P.1-46. 